\title{
A Visual Semiotics Analysis on Webtoon Sweet Home
}

\author{
PUJA INDRIANA NASUTION ${ }^{1}$, RAHMADSYAH RANGKUTI ${ }^{2}$, MUHAMMAD YUSUF $^{3}$ \\ ${ }^{1}$ Universitas Sumatera Utara, J. Dr. T. Mansur No 9, Medan, Indonesia \\ pujaindriani28@gmail.com \\ ${ }^{2}$ Universitas Sumatera Utara, J. Dr. T. Mansur No 9, Medan, Indonesia \\ syahkuti@gmail.com \\ ${ }^{3}$ Universitas Sumatera Utara, J. Dr. T. Mansur No 9, Medan, Indonesia \\ yusuf_my@usu.ac.id
}

\begin{abstract}
Webtoon is one of the media in delivering thoughts, point of view and life values with others, especially entitled sweet home. By using visual semiotic analysis, this study aimed to identify signs used in the Webtoon Sweet Home and to interpret the meanings of the Semiotic signs used in the Webtoon. The data source of this study is the serial comic entitled Sweet Home in the Webtoon which were technically collected using the qualitative method and visual materials in addition to applying the LINE Webtoon. Twenty six data were analyzed using the Visual Semiotic study proposed by Charles Sanders Peirce, including representamen, object, and interpretant. Additionally, this study used three steps in interpreting the signs namely, non-verbal communication legisign, framing techniques and communicative act. The study found that legisign was used on the panels in the Webtoon Sweet Home that has general information in which the writer wishes to tell the readers. The legisign represents the meaning of the images portrayed in the Webtoon. Furthermore, the non-verbal communication legisign was identified based on facial expression, body language, posture, and gesture. The framing technique concern what image shows, and the communicative act was analyzed based on the verbal sign found the Webtoon Sweet Home.
\end{abstract}

Keywords: sweet home webtoon. line webtoon, visual semiotics, peirce, sign, meaning 


\title{
Sebuah Analisis Semiotika Visual pada Webtoon Sweet Home
}

\begin{abstract}
Abstrak
Webtoon adalah salah satu dari media dalam menyampaikan ide, sudut pandang, dan nilai kehidupan dengan orang lain, khususnya yang berjudul Sweet Home. Dengan menggunakan analisis semiotika visual, penelitian ini bertujuan untuk mengidentifikasi tanda-tanda yang digunakan dalam Webtoon Sweet Home. Sumber data dari penelitian ini adalah serial komik Sweet Home di Webtoon yang secara teknis dikumpulkan menggunakan metode kualitatif dan materi visual dari LINE Webtoon. Dua puluh enam data dianalisis menggunakan Semiotika Visual yang dikembangkan Charles Sanders Peirce meliputi representamen, objek, dan interpretant. Selanjutnya, penelitian ini menggunakan tiga langkah dalam menginterpretasi tanda-tanda seperti komunikasi nonverbal legisign, teknik framing, dan tindakan komunikatif. Penelitian ini menemukan bahwa legisign digunakan dalam panel di Webtoon Sweet Home yang mengandung informasi umum dimana penulis harapkan kepada pembaca. Legisign merepresentasikan makna dari gambar yang ditampilkan dalam Webtoon. Kemudian, komunikasi nonverbal legisign ditunjukkan melalui ekspresi wajah, bahasa tubuh, postur, dan gesture. Teknik framing memperhatikan apa yang ditampilkan gambar, dan tindakan komunikatif dianalisis berdasarkan tanda verbal yang ditemukan pada Webtoon sweet Home.
\end{abstract}

Kata Kunci: webtoon sweet home, webtoon line, semiotika visual, pierce, tanda, makna

\section{INTRODUCTION}

Comics are stories that emphasize motion and movement and are expressed through a series of visuals made in a unique way using a combination of text and images (Franz and Meier 1994, p.55). In his book Understanding Comics, Scott McCloud (1993) explains that comics are images that convey information or evoke an aesthetic response from the readers. Relationships between visual images or symbols and words or verbal symbols make up almost all comic texts. Images in comic books are a series of image sequences that are linked together to tell a story. In this regard, McCloud (1993, pp.9) defines comics as "images and other symbols juxtaposed in a precise order to transmit information and possibly generate aesthetic responses from readers". According to McCloud (1993), sequential images are a superior mode of communication. It can be used to deliver non-fictional 
scientific messages. Meanwhile, words in comics serve to explain, complete, and deepen the overall delivery of images and text.

In this study, the researcher examined at the existing comic strips to see how they could be analyzed using Semiotics. The science of signs is known as Semiotics. Semiotics is the study of signs and everything related to them, including how they function, their relationship to other signs, and how they are transmitted and received by those who use them. It also studies the systems, rules, and conventions that allow these signs to have meaning (Kriyantono and Sos 2014, p.261). According to Kress (2004) semiotics is a science of the sign, a fusion of form (signifier) and meaning (signified). Visual semiotics refers to sub-domain of semiotics which discuss the way visual images communicate a message. There are 3 popular philosophers in this field, they are Ferdinand de Saussure, Roland Barthes and Charles Sanders Pierce.

The following examples highlight what data is and how the formal objects in this study are analyzed.

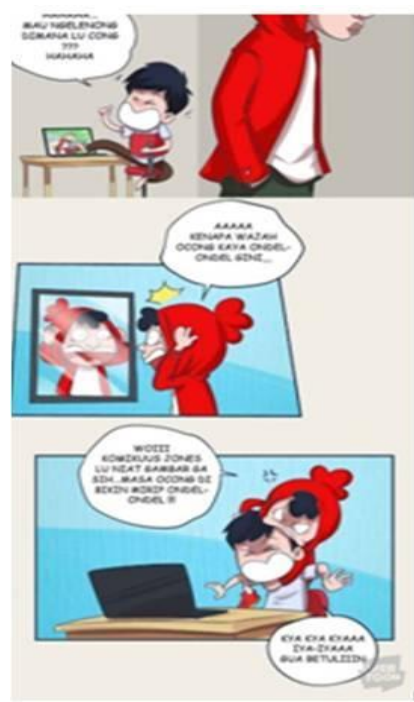

Figure 1

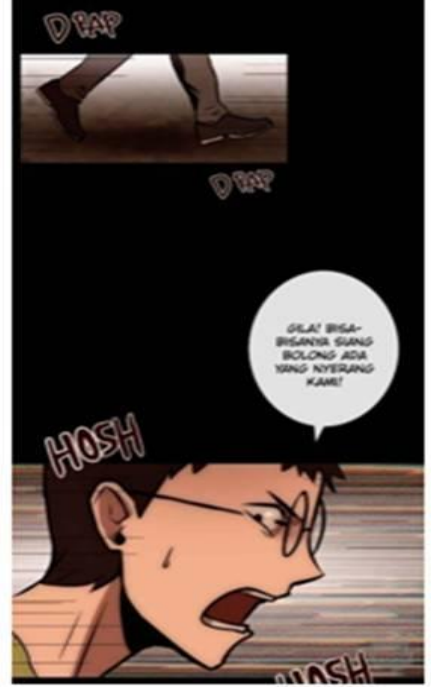

Figure 2

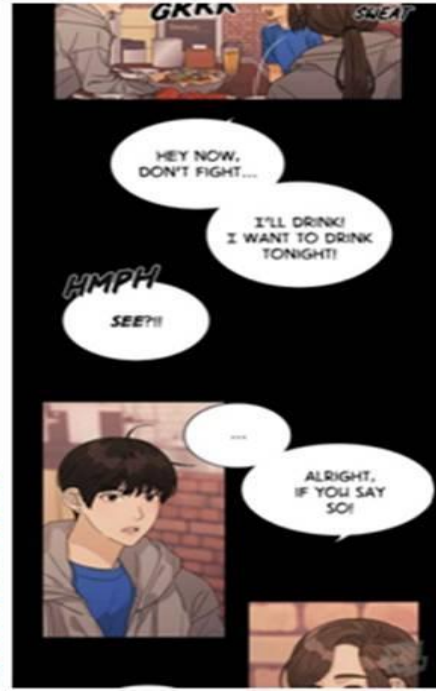

Figure 3

Samples of Webtoon Online Comics

The above exemplified parts of comics are the online comics that we can read on the Webtoon. We can see from the comic above where now comics are made in a more colorful form. To read comics online on a Webtoon, we can change the language settings needed, as in Figure 1, it is a comic entitled Si Ocong with the comedy genre, where the comic is read in Indonesian language settings. Furthermore, in figure 2, it is a horror comic with the title Bloody Gaze which is 
also read in Indonesian language setting, and figure 3 which is a romance comic titled To Love Your Enemy which is read in English language setting.

In this study, the researcher analyzed a Webtoon entitled Sweet Home by Using Pierce's Theory triadic sign, where he proposed trichotomy namely, Representamen, Object and Interpretant to identify the sign and rhetorical function of verbal and non-verbal sign since comic combined text and image. Pierce stated that the process of semiosis involves a triadic relationship between a sign or representament (a first), an object (a second) and an interpretant (a third). The representament here stands for another thing (object). The representamen can be a qualisign (firstness), a sinsign (secondness), and a legisign (thirdness). The object can be a symbol, index or may be an icon that has relation between sign and its object. While interpretant can be divided into a rheme (firstness), a dicisign or dicent sign (secondness) and an argument or reasoning (thirdness). This is why the author applied sign theory by Pierce, because the purpose of this study is to find out how the Webtoon was used in verbal and non-verbal communication since the comic combined text and image.

There have been many studies on Semiotic analysis, among others; Peircean triadic theory on taglines advertisements (Yohana 2015); Semiotics analysis on Fair and Lovely Ads (Dwita 2018), Semiotic signs in movie poster (Hawan 2018); Semiotic study of gender construction of women on Instagram (Nurrohman and Wirawanda 2018); visual semiotics analysis on television ads UHT Ultra Milk (Ardhianto and Son 2019); and Semiotic Analysis of Meme on Instagram (Murtaisah 2020). None of these previous studies have discussed about the visual Semiotic analysis on comics. The reason underlying the use of Sweet Home as the research object in this study is because currently the Webtoon is being considered as one of the reading media used by many people. The word becomes a film because the topic of the story is interesting to read. Owner of Webtoon helps readers to better understand a story and can make the story feel more real because it is illustrated in images. Then, this research can also help the connoisseurs of the Sweet Home story to understand the verbal and non-verbal signs in this comic. Moreover, semiotics has been widely used to analyze posters and advertisements, so this research will analyze objects that are not widely discussed, namely the Webtoon.

Based on the background above, there are two problems in this study, what are the semiotic signs used in Webtoon Sweet Home? and How are the semiotic https://doi.org/10.52187/rdt.v2i3.42|178 
signs used in Webtoon Sweet Home interpreted? The objectives of the study are to identify the semiotic signs used in Webtoon Sweet Home, to interpret the meaning of the semiotic signs used in Webtoon Sweet Home. This study is focused semiotic sign used and how it will be interpreted on Webtoon Sweet Home. And the data that will be analyzed is the 7 th episode which was published on $18^{\text {th }}$ February 2018.

This study can hopefully contribute both theoretically and practically, theoretically this study is intended to help in improving the analysis of sign by using semiotics field. By reading this study the author expected the readers can get better understanding to interpret the meaning of an object. This is expected to give more information for the students, especially English students for helping them to know how to use visual Semiotics to interpret the meaning from objects which reflect both images and text.

\section{REVIEW OF RELATED LITERATURE}

\section{Semiotics}

Semiotics is defined as a science that studies a wide range of objects, events, all cultures as signs (Sonesson 2011). Charles Shanders Peirce (1839-1914), a wellknown American philosopher, introduced a triadic definition of sign in the field of semiotics, in which a sign consists of a representamen, an interpretant, and an object. A sign (representamen), according to Peirce, is something that is used to represent something else within certain limits (Eco 2010). The sign will always point to something else, which Peirce referred to as the object (denotatum). To represent or replace means to direct. The new sign is useful if it is interpreted in the mind of the sign's recipient by the interpretant. As a result, the interpretant is a comprehension of the meaning that appears in the mind of the sign's recipient.

According to Peirce's viewpoint, a sign can represent something else, and thus a sign represents something that represents it. The term representamen refers to the representation of something that is represented $(\mathrm{X})$. Because a sign is a representation of something, it must represent something, such as a representation of an object, a figure, or something else, which is referred to as an object $(\mathrm{Y})$.

An interpreter $(\mathrm{X}=\mathrm{Y})$ is something that can be interpreted by others or the meaning that is in someone's mind about the object referred to by a sign. Three 
elements that present signification semiotics, namely Representamen (X), Object $(\mathrm{Y})$, and Interpretant $(\mathrm{X}=\mathrm{Y})$ (Kriyantono and Sos 2014, p. 265).

According to Peirce, a sign is an instance of Firstness, while its object is an instance of Secondness, and its interpreter - the intermediate element - is an instance of Thirdness. Peirce was looking for the structure of the three, wherever the three might be. All three give rise to unlimited Semiosis in the context of sign production, insofar as the interpreter (idea) who reads the sign as a sign of something (ie as a representation of meaning or reference) can always be understood by other interpreters. The interpreter is a central aspect for linking a person to his object (three important types of interpreters are induction, deduction, and retrieval (hypothesis). A sign must be interpreted in order to exist as a sign (and therefore have an interpreter) (Lechte 1994, p. 167). Thus, a meaning depends on a person's image or thought in relation to the sign and the thing represented by the sign (Littlejohn and Foss 2010, p.55). The following table describes Pierce's Triadic Theory

\begin{tabular}{llll}
\hline \multicolumn{1}{c}{$\begin{array}{c}\text { Category } \\
\text { Trichotomy }\end{array}$} & \multicolumn{1}{c}{ Firstness } & Secondness & Thirdness \\
\hline Representament & Qualisign & Sinsign & Legisign \\
Object & Icon & Index & Symbol \\
Interpretant & Rheme & Dicisign & Argument \\
\hline
\end{tabular}

The object of this research is images. Based on the reason, the researcher needs to identify lesisign or more properly the case of images, verbal and nonverbal communication lesisign. The next step is to identify the system of nonverbal communication which involves the framing technique and the communicative act. In visual arts the term framing technique is the presentation of visual elements in an image, especially the placement of the subject in relation to other objects. A communicative act is an utterance, or set of utterances which is used to perform the linguistic action or function in communication. Ie., when we use language to invite someone or complain about something.

Non-verbal communication legisigns can be analyzed through the following details; a) Bodily contact: this is culturally variable and determines who touches whom, where and in what circumstances. b) Proximity or interpersonal spacing: this is culturally variable and determines how far the space between one and another. c) Facial expression: usually accompanied to speech and like posture is a reliable 
indication of someone's emotional state. d) Gestures: body movement with meaning and some gestures are culturally distributed. e) Posture: interpersonal attitude and can be an indication of one's emotional state along a tense-relaxed dimension. f) Appearance: self-representation that is sending out signals about the self, such as, one's personality, mood, social status, occupation, or the social group one belongs to.

\section{Visual Semiotics}

The data in this research is the image and its caption from webtoon entitled Sweet Home. Due to that reason the researcher needs to use visual semiotics to analyze the data, because the researcher will analyze the combination image and text at the same time. Visual semiotics is a sub-branch of semiotics which study how an image conveys a message or meaning. Most works of art perform images rather than text, or maybe sometimes they can have both. Then, connecting the image and text by reading the text on the image can affect the reader's understanding, so the meaning of words and images or image influence each other. That's why visual signals are not arbitrary.

\section{Webtoon Sweet Home}

Sweet Home is a Webtoon series that is written by Carnby Kim and Youngchan Hwang. This Webtoon was released on $15^{\text {th }}$ January 2018 and the last episode was released on 29th September 2020. Sweet Home is a feature thriller Webtoon that tells about a senior high school student who is very close, even with his family he is very closed off. One day he was forced to leave his home because of an unexpected incident. This is how it all changed. There are 141 sub stories in this Webtoon, and the researcher takes the $7^{\text {th }}$ series to be analyzed.

\section{RESEARCH METHOD}

This study was designed with a qualitative research method using a semiotic approach and descriptive analysis to study the meaning and images in comics. The qualitative method enables the researcher to collect and analyze the data deeply, describe and interpret the results and explain about the signs expressed in Webtoon Sweet Home (Ollerenshaw and Creswell 2002). The data is the 7 th episode which was published in June 12thFeburary 2018 and it was accessed on (www.webtoons.com). The source of data used in this research is taken from the Webtoon entitled Sweet Home written by Carnby Kim and Youngchan Hwang. The 
genre of this Webtoon is thriller which is about the condition of the world where humans turned into monsters due to their deepest desires. The data are visual and verbal signs in the Webtoon Sweet Home. The verbal signs are the written texts of the panel in the Webtoon consisting of words, phrases, clauses and sentences. The visual signs are the images in the Webtoon. The data in this study were taken from the 7th episode of Webtoon Sweet Home that were collected to follow a number of steps including a) downloading the Webtoon Sweet Home to get the softcopy data; b) reading all of the episodes in this Webtoon and choose one of the episodes to be analyzed; c) taking some panels from the chosen episode of the Webtoon Sweet Home; d) taking notes on both verbal and non-verbal signs and analyzed their meanings. The data were analyzed based on an interactive model proposed by Miles, Huberman, and Saldana (2014) which were divided into three phases. It consists of data reduction, data display, and drawing and verifying conclusions.

\section{FINDINGS AND DISCUSSION}

\section{The Findings}

This chapter describes how to analyze the data by transforming raw data into useful information. The result of the data analysis is to answer the problem of the study: what are the semiotic signs used in Webtoon Sweet Home? And how are the semiotic signs used in Webtoon Sweet Home interpreted? The raw data in this research is the 7 th episode of Webtoon of sweet home and there are 31 images of Webtoon Sweet Home but I analyzed 9 images of Webtoon Sweet Home. These following are the analysis of the data by using Pierce's visual semiotic analysis. The sign which is found in the $7^{\text {th }}$ episode of Webtoon Sweet Home is displayed in a table as the answer of the first problem and followed by meaning as the answer of the second problem. 


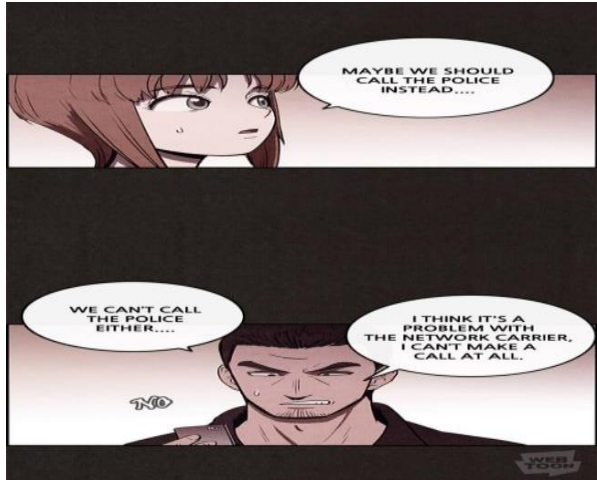

Figure 4. Data 1
Sign : The girl surprised and

(Legisign) the man is mad and confused

Object(Icon) : Pyeon Sang Wook and Yoon Ji Su

Interpretant

(Rheme)
: The image shows Ji Su worried and tried to give suggestion, while the man was mad and confused at the same time.

After identifying the signs found in the data, I apply 3 steps of analysis model, among others; analyzing non-verbal communication legisign. In this Webtoon it was analyzed based on Sang Wook and Ji Su's facial expressions. According to Joumana Medlej in the human anatomy fundamentals series. The data identifiable that Sang-Wook showed an upset expression and $\mathrm{Ji} \mathrm{Su}$ showed a worried expression. Worries can be shown by the head is usually simultaneously jerked back, the mouth puckers, wide and rounded eyes, and the mouth may be slightly open. Upset is milder than anger, but it is clear that there is a disturbance felt by the person. The state of upset is identifiable from the head of the eyebrows moving downward, the jaw tense, and the watchful eye. From the framing technique. The frame takes the girl who gave a suggestion to the man for calling the police, but the man found a network problem that caused them couldn't call the police.

In terms of the communicative act. The verbal sign that was found in the Webtoon is the caption in the balloon speech "Maybe we should call the police instead...", "we can't call the police either..." and "I think it's a problem with the network carrier, I can't make a call at all". The sentence is a suggestion and statement. The girl was surprised with their condition and tried to help by giving suggestions but it didn't work because of network problems. 


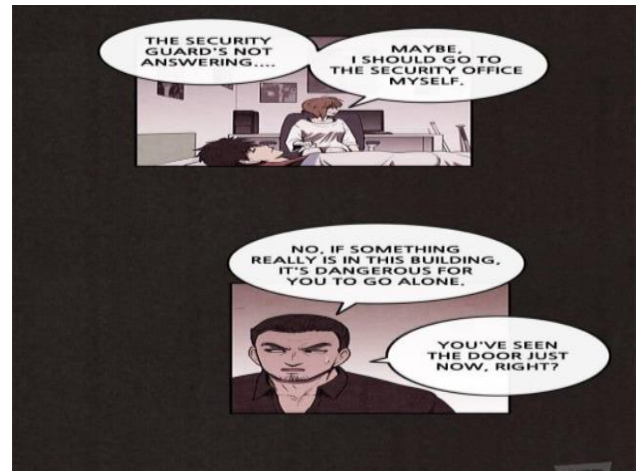

Sign : They are shock

(Legisign)

Object(Icon) : Pyeon Sang Wook, Yoon Ji Su, and Cha Hyun Soo

Interpretant The image shows that

(Rheme) : they were struck by something

Figure 5. Data 2

The sign used is legisign since the Webtoon shows the meaning through an object by general expression of shock. The object can be categorized as icon because an icon is a sign which resembles the object, while the character in Webtoon is a figurative image and resembles the object, therefore it is an icon. Rheme stands for its object in respect of quality. After identifying the signs, I apply 3 steps of analysis model, among others; the first is analyzing non-verbal communication legisign. In this webtoon it is interpreted based on Sang Wook and Ji Su's facial expressions and gesture. According to Joumana Medlej in human anatomy fundamentals series (Envato, 2021), Sang-Wook shows puzzle expression while Ji Su shows uncertain or worried expression. Puzzle expression can be seen by narrowed eyes and wrinkled eyebrows, reflexively the eyebrows will be raised because of worry or anxiety. Uncertain or shocked expressions of Ji Su can be seen by her facial expression and her body gesture. Ji Su's expressions and gestures can be seen by his jaw dropping, mouth still narrow but open, eyebrows raised, and gestures he makes by facing sideways, towards something he is suspicious of.

The next step is analyzing the framing technique. The frame shows both of them are curious and worried about something happening out of the door. The last step is analyzing the communicative act. The verbal sign that was found in the Webtoon is the caption in the balloon speech "the security guard's not answering..." "Maybe, I should go to the security office myself" "no, if something really is in this building, it's dangerous for you to go alone" and "you've seen the door just now, right?" The sentence is a statement and a question which ends with a question mark. We can conclude they are just curious and worried whether it's okay or not to go out. 


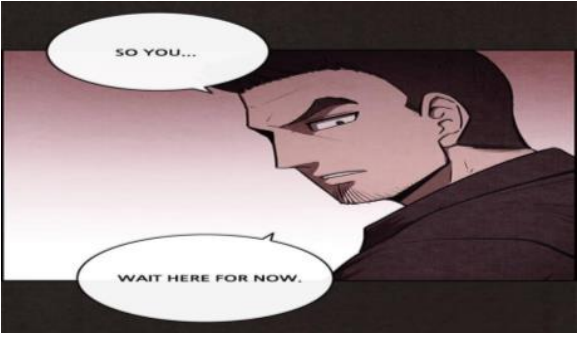

Figure 6. Data 3
Sign : Puzzling person.

(Legisign)

Object(Icon) : Pyeon Sang Wook

Interpretant : The image shows that (Rheme)
Sang Wook asked Ji Su to wait in the room

The sign used is legisign since the Webtoon shows the meaning through an object by general expression of puzzled. The object can be categorized as icon because icon is a sign which resembles the object, while the character in Webtoon is figurative image and resembles the object, therefore it is an icon. Rheme stands for its object in respect of quality. After identifying the signs, I apply 3 steps of analysis model, among others; the first step is analyzing non-verbal communication legisign. In this webtoon it was analyzed based on According to Joumana Medlej in human anatomy fundamentals series (Envato, 2021), Sang Wook shows puzzled expressions. Puzzled expression here can be seen by his raised eyebrows and a slightly confused expression on his face. This seemed clearer than what he said to Ji Su. Sang Wook looked confused until finally he decided to just tell them to wait in the room. The next step is analyzing the framing technique. The frame takes Sang Wook's face, so that it's focusing on his face or facial expression. The last step is analyzing the communicative act. The verbal sign that found in the Webtoon is the caption in the balloon speech "So you wait here for now". This sentence is a statement. We can conclude that Sang Wook just wants to save them by asking them to stay in the room.

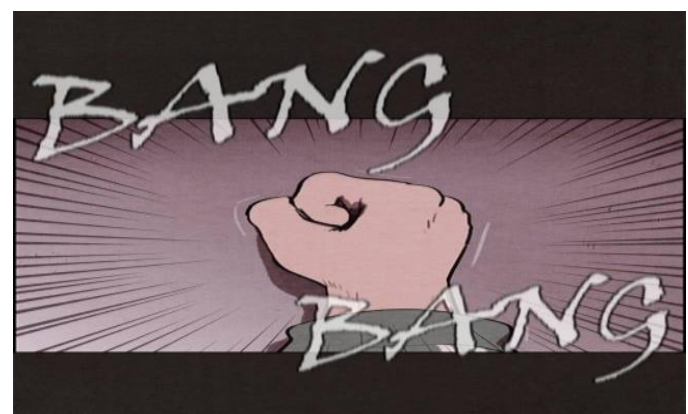

Figure 7. Data 4
Sign (Legisign) : Door is knocked by someone.

Object (Icon)

: Someone's hand

Interpretant

(Rheme)
: The image shows a door being knocked by someone's hand. 
The sign used is legisign since the Webtoon shows the meaning through an object by general body gesture of knocking the door. The object can be categorized as icon because icon is a sign which resembles the object, while the character in Webtoon is figurative image and resembles the object, therefore it is an icon. Rheme stands for its object in respect of quality. After identifying the signs, I apply 3 steps of analysis model, among others; the first steps is analyzing non-verbal communication legisign. In this Webtoon, it was analyzed based on someone's hand gesture that knocked the door. The next step is analyzing the framing technique. The frame takes a door is knocked by someone's hand, so that is focusing on the door. The last step is analyzing the communicative act. The verbal sign found in the Webtoon is the caption in the image is "bang bang" which shows how a door is knocked sounds like. We can conclude that this scene is focusing on the knocking door.

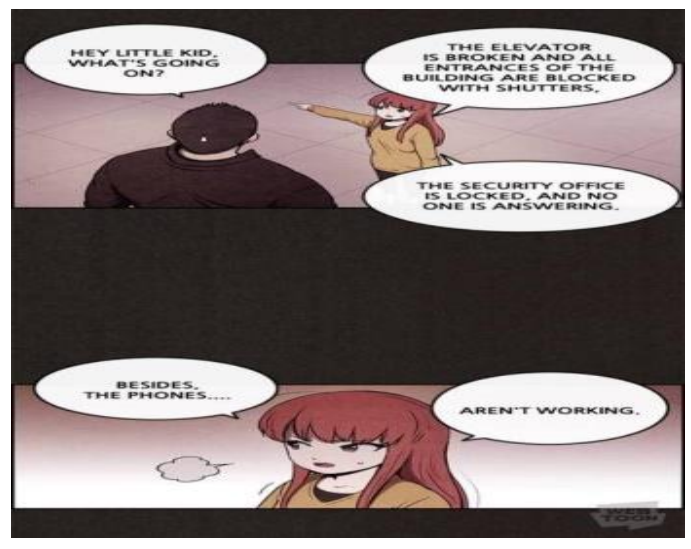

Sign (Legisign) : Feeling curious

Object(Icon) : Pyeon Sang Wook and Lee Eun Yu

Interpretant : The image shows that (Rheme) Eun Yu told and explained something to Sang Wook.

Figure 8. Data 5

The sign used is legisign since the Webtoon shows the meaning through an object by general expression of curious. The object can be categorized as icon because icon is a sign which resembles the object, while the character in Webtoon is figurative image and resembles the object, therefore it is an icon. Rheme stands for its object in respect of quality. After identifying the signs, I apply 3 steps of analysis model, among others; the first step is analyzing non-verbal communication legisign. In this Webtoon it was analyzed based on Eun Yu's facial expression and her body gesture. According to Joumana Medlej in human anatomy fundamentals series (Envato, 2021) Eun Yu shows curious expression, it can be seen by an ordinary expression turning into an expression of interest that is expressed in the 
eye area, the eyebrows raised, the eyes become alert and focus is further clarified by Eun Yu's body gesture which points at something that makes them curious and her mouth opens as if to take in more. The next step is analyzing the framing technique. The frame takes Eun Yu told something to Sang Wook, so that's focusing on Eun Yu's facial expression and body gesture. The last step is analyzing the communicative act. The verbal sign that found in the Webtoon is the caption in the balloon speech "hey little kid, what's going on?" "the elevator is broken and all entrances of the building are blocked with shutters," "the security office is locked, and no one is answering," "besides, the phones..." and "aren't working". Those sentences are statement and question. We can conclude that they were talking about the broken elevator.

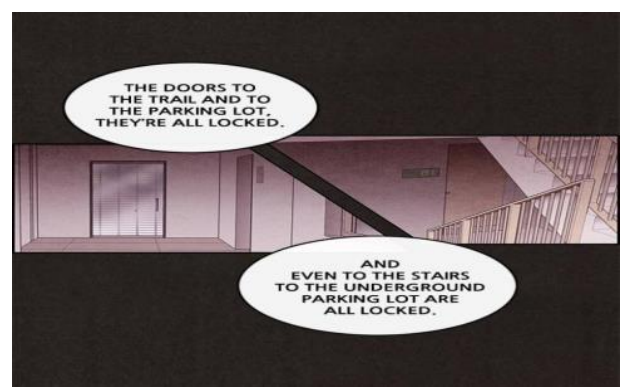

Figure 9. Data 6
Sign (Legisign) : an empty room

Object(Icon) : a room

Interpretant : The image shows that (Rheme) there was possibility the people are locked in the room.

The sign used is legisign since the Webtoon shows the meaning through an object by the quiet situation. The object can be categorized as icon because icon is a sign which resembles the object, while the character in Webtoon is figurative image and resembles the object, therefore it is an icon. Rheme stands for its object in respect of quality. After identifying the signs, I apply 3 steps of analysis model, among others; the first step is analyzing non-verbal communication legisign. In this Webtoon it was analyzed based on the room situation. The next step is analyzing the framing technique. The frame takes an empty room. The last step is analyzing the communicative act. The verbal sign that found in the Webtoon is the caption in the balloon speech "the doors to the trail and to the parking lot. They're all locked" and "and even to the stairs to the underground parking lot are all locked". Those sentences are statement. We can conclude all the room were locked. 


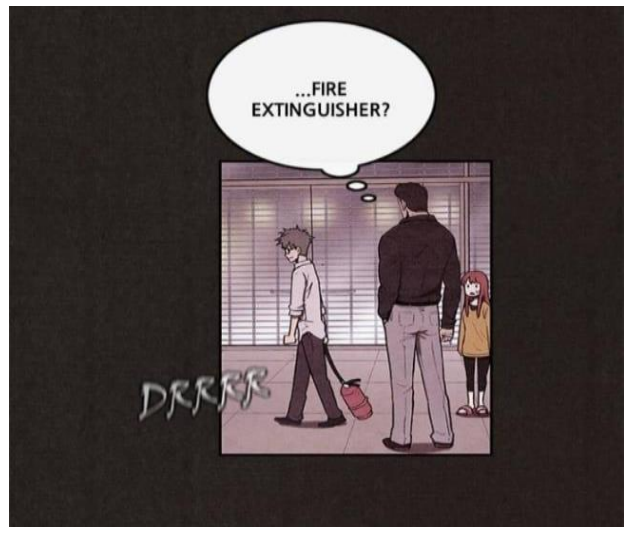

Sign (Legisign) : Feeling curious

$\begin{aligned} \text { Object(Icon) : } & \text { Cha Hyun Soo, Pyeon } \\ & \text { Sang Wook, and Lee } \\ & \text { Eun Yu }\end{aligned}$

Interpretant : The image shows that (Rheme) they were curious why Hyun Soo bring fire extinguisher.

Figure 10. Data 7

The sign used is legisign since the Webtoon shows the meaning through an object by general expression of curious. The object can be categorized as icon because icon is a sign which resembles the object, while the character in Webtoon is figurative image and resembles the object, therefore it is an icon. Rheme stands for its object in respect of quality. After identifying the signs, I apply 3 steps of analysis model, among others; the first step is analyzing non-verbal communication legisign. In this webtoon it was analyzed based on Sang Wook's body gesture and Hyu Soo's body gesture. According to Joumana Medlej in human anatomy fundamentals series (Envato, 2021), Hyun Soo shows so-so gesture because he walked casually without any suspicious movements, while Sang Wook and Eun Yu looked curious on Hyun Soo. The next step is analyzing the framing technique. The frame takes Sang Wook and Eun Yu were looking at Hyun Soo. The last step is analyzing the communicative act. The verbal sign that found in the Webtoon is the caption in the balloon speech "fire extinguisher?". This sentence is question. We can conclude that they were wondering why Hyun Soo brought fire extinguisher.

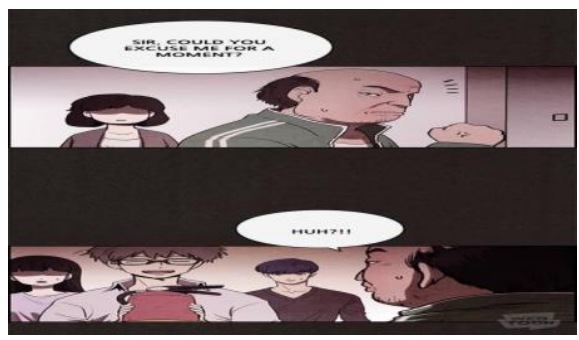

Figure 11. Data 8

$\begin{array}{ll}\text { Sign (Legisign) } & : \text { Feeling awkward } \\ \text { Object(Icon) } & : \begin{array}{l}\text { Cha Hyun Soo, and old } \\ \text { man, and others }\end{array} \\ \begin{array}{l}\text { Interpretant } \\ \text { (Rheme) }\end{array} & \begin{array}{l}\text { The image shows that } \\ \text { Hyun Soo looked awkward } \\ \text { in front of the old man }\end{array}\end{array}$

Sign (Legisign) : Feeling awkward Cha Hyun Soo, and old The image shows that in front of the old man

The sign used is legisign since the Webtoon shows the meaning through an object by general expression of awkward. The object can be categorized as icon 
because icon is a sign which resembles the object, while the character in Webtoon is figurative image and resembles the object, therefore it is an icon. Rheme stands for its object in respect of quality. After identifying the signs, I apply 3 steps of analysis model, among others; the first step is analyzing non-verbal communication legisign. In this Webtoon it was analyzed based on Hyun Soo's facial expression and an old man's facial expression. According to Joumana Medlej in human anatomy fundamentals series (Envato, 2021), Hyun Soo show ecstatic expression, it can be seen by his true broad smile, visible teeth that are a strong sign of happiness, but he also looks awkward in front of the old man. While the old man looks upset, it can be seen by the heads of the eyebrows move down, and the jaw is tensed into biting posture that pushes the lower lip forward and makes the mouth curve down. The next step is analyzing the framing technique. The frame takes Hyun Soo smile awkwardly. The last step is analyzing the communicative act. The verbal sign that found in the Webtoon is the caption in the balloon speech "sir, could you excuse me for a moment?" and "huh?!!" . Those sentences are questions. We can conclude that the situation was so awkward and confusing.

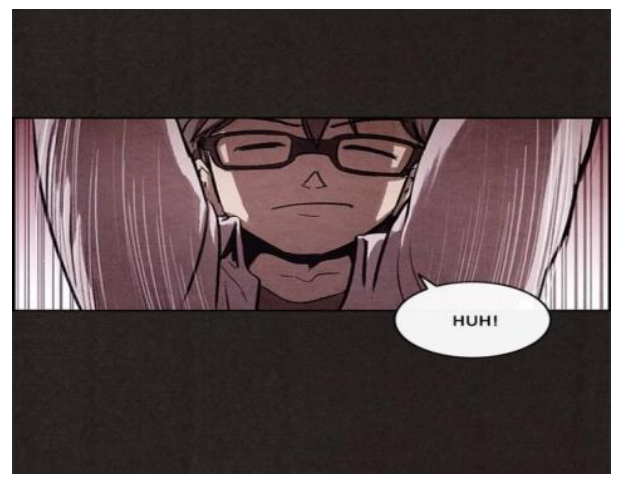

Sign (Legisign) : Feeling oppressed

Figure 12. Data 9

Object (Icon) : Cha Hyun Soo

Interpretant : The image shows that (Rheme) Hyun Soo lift something

The sign used is legisign since the Webtoon shows the meaning through an object by general expression of oppressed. The object can be categorized as icon because icon is a sign which resembles the object, while the character in Webtoon is figurative image and resembles the object, therefore it is an icon. Rheme stands for its object in respect of quality. After identifying the signs, I apply 3 steps of analysis model, among others; the first step is analyzing non-verbal communication legisign. In this Webtoon it was analyzed based on Hyun Soo's facial expression. According to Joumana Medlej in human anatomy fundamentals series (Envato, 2021), Hyun Soo shows sneering expression. Sneering expression is response to 
something despised, be it physical or moral. It can be seen by the lower lip pushes up, curving the mouth down, and the eyes are alert but narrowed. The next step is analyzing the framing technique. The frame takes Hyun Soo lift something. The last step is analyzing the communicative act. The verbal sign that found in the Webtoon is the caption in the balloon speech "Huh!" That sentence is exclamation sentence. We can conclude that Hyun Soo was feeling uncomfortable about something.

\section{Discussion}

From the result of the data analysis based on Charles Sander Peirce's theory (1931), each panel of the Webtoon consists of sign (legisign), object (icon) and interpretant (rheme) which stand for a meaning or idea conveyed by the Webtoon creator. There are 26 signs found in the Webtoon Sweet Home episode $7^{\text {th }}$, as follow: The sign found in the data 1 are Lesisign the girl surprised and the man is mad and confused, the icon is Pyeon Sang Wook and Yoon Ji Su, and the interpretant is they are surprised and mad. While the interpretation of sign on this Webtoon through 3 steps, they are facial expression, framing technique, and communicative act.

The sign found in the data 2 are Lesisign they are shock, the icon is Pyeon Sang Wook, Yoon Ji Su, and Cha Hyun Soo, and the interpretant is they were struck by something. While the interpretation of sign on this Webtoon through 3 steps, facial expression and gesture, framing technique, and communicative act. The sign found in the data 3 are legisign signified by the act of giving an order. The icon is Pyeon Sang Wook, and the interpretant is Sang Wook asked Ji Su to wait in the room. While the interpretation of signs use on this Webtoon were done through 3 steps, they are facial expression, framing technique, and communicative act.

The sign found in the data 4 are Legisign is Door is knocked by someone, the icon is someone's hand, and the interpretant is door is knocked by someone's hand. While the interpretation of sign on this Webtoon through 3 steps, gesture, framing technique, and communicative act. The sign found in the data 5 are Legisign is Eun Yu told something, the icon is Pyeon Sang Wook and Lee Eun Yu, and the interpretant is Eun Yu told and explained something to Sang Wook. While the interpretation of sign on this Webtoon through 3 steps, facial expression and her body gesture, framing technique, and communicative act.

The typical sign found in the data 6 are Legisign is an empty room, the icon is a room, and the interpretant is there was possibility the people were locked in the room. While the interpretation of sign on this webtoon was seen from 3 steps, 
certain situation, framing technique, and communicative act. The sign found in the data 7 are legisign is, feeling curious, the icon is Cha Hyun Soo, Pyeon Sang Wook, and Lee Eun $\mathrm{Yu}$, and the interpretant is they were curious why Hyun Soo. While the interpretation of sign on this Webtoon were done through 3 steps, body gesture, framing technique, and communicative act. Then, the sign found in the data 8 are Legisign is Feeling awkward, the icon is Cha Hyun Soo, and old man, and others, and the interpretant is Hyun Soo looked awkward in front of the old man. While the interpretation of sign on this Webtoon through 3 steps, certain situation, framing technique, and communicative act. The sign found in the data 9 are Legisign is Feeling oppressed, the icon is Cha Hyun Soo, and the interpretant is Hyun Soo lift something. While the interpretation of sign on this Webtoon through 3 steps, certain situation, framing technique, and communicative act.

The panels interact, creating an even larger sign in the comic. The episode $7^{\text {th }}$ of Webtoon Sweet Home, in the one hand the trichotomies describe respectively the Representament in itself; the relation between Representamen and Object; and the relation between Representamen and interpretant. According to Peircean definition, a sign is not interpreted exclusively as an icon, an index or a symbol. Similarly in this study, typical signs used in the Webtoon include representamen (legisign), object (icon), and interpretant (rheme). The writer seemed to have chosen the legisign because the panels in the Webtoon Sweet Home has general information that the writer wishes to tell the readers. The legisign represents the meaning of the images portrayed in the Webtoon. Second, the non-verbal communication aspects include legisign, framing techniques, and communicative act. The non-verbal communication legisign was identified based on facial expression, body language, posture and gesture. The framing technique concern what image shows, and the communicative act was analyzed based on the verbal sign found the Webtoon Sweet Home.

\section{CONCLUSION}

After analyzing the episode $7^{\text {th }}$ of Webtoon Sweet Home, the researcher concludes some points. First, the researcher found that typical signs used in the Webtoon include representamen (legisign), object (icon), and interpretant (rheme). Additionally, the writer chose to use legisign since the panels in the Webtoon Sweet Home has general information that the writer wishes to tell the readers. The https://doi.org/10.52187/rdt.v2i3.42| 191 
legisign represents the meaning of the images portrayed in the Webtoon. Second, the non-verbal communication aspects include legisign, framing techniques, and communicative act. The non-verbal communication legisign was identified based on facial expression, body language, posture and gesture. The framing technique concern what image shows, and the communicative act was analyzed based on the verbal sign found the Webtoon Sweet Home.

\section{REFERENCES}

Ardhianto, Peter, and William Manuel Son. 2019. "Visual Semiotics Analysis on Television Ads UHT Ultra Milk 'Love Life, Love Milk." International Journal of Visual and Performing Arts 1(1):27-41. doi: 10.31763/viperarts.v1i1.13.

Bagus Nurrohman, Dwi, and Yudha Wirawanda. 2018. "Gender in Social Media:

Semiotic Study of Gender Construction of Women in Instagram Account @Moduskeras Postings." Komunikator 10(2):112-26. doi:

\subsection{6/jkm.101010.}

Dwita, Desliana. 2018. "Gender Equality in Media Television (Semiotics Analysis of Fair and Lovely Advertisement Issue of Marriage or Master Degree)." Komuniti: Jurnal Komunikasi Dan Teknologi Informasi 10(1):37-43.

Eco, Umberto. 2010. Teori Semiotika Signifikasi, Teori Kode Serta Teori Produksi Tanda.

Franz, Kurt, and Bernhard Meier. 1994. "Membina Minat Baca Anak." Bandung: Remaja Rosdakarya.

Hawan, M. Rizki. 2018. "An Analysis of Semiotic Signs Found in Movie Poster of Pirates of the Caribbean."

Kress, Gunther. 2004. "Reading Images: Multimodality, Representation and New Media." Information Design Journal 12(2):110-19.

Kriyantono, Rachmat, and S. Sos. 2014. Teknik Praktis Riset Komunikasi. Prenada Media.

Lechte, John. 1994. "Walter Benjamin." Fifty Key Contemporary Thinkers-From Structuralism to Postmodernity. London and New York: Routledge, 1994. Print. Littlejohn, Stephen W., and Karen A. Foss. 2010. Theories of Human Communication. Waveland press.

Mariska Yohana, Fenti. 2015. "A Semiotic-Analysis Based on Peirce Triadic Theory on Taglines of Nokia, Honda, Airasia, Lg and You C 1000 Advertising." Deiksis $7(01): 13-22$. 
McCloud, Scott. 1993. "Understanding Comics: The Invisible Art." Northampton, Mass.

Miles, Matthew B., A. Michael Huberman, and Johnny Saldana. 2014. "Qualitative Data Analysis: A Methods Sourcebook."

Murtaisah, Dewi. 2020. "Semiotics Analysis of Meme for Woman At@9gaggirly Instagram Account."

Ollerenshaw, jo Anne, and John W. Creswell. 2002. "Narrative Research: A Comparison of Two Restorying Data Analysis Approaches." Qualitative Inquiry 8(3):329-47. doi: 10.1177/10778004008003008.

Sonesson, Göran. 2011. "Semiotics Inside-Out and/or Outside-In. How to Understand Everything and (with Luck) Influence People." Signata. Annales Des Sémiotiques/Annals of Semiotics (2):315-48. 